\title{
The Role of Social Media Marketing in Ecotourism: Perspectives of Tourists Visiting Totally Protected Areas (TPAs) in Sarawak, Malaysia
}

\author{
JUN ZHOU THONG ${ }^{1}$, MAY CHIUN LO ${ }^{2}$, T. RAMAYAH ${ }^{3}$, ABANG AZLAN MOHAMAD ${ }^{4}$ \\ ${ }^{1}$ Faculty of Economics and Business, UNIVERSITI MALAYSIA SARAWAK, MALAYSIA. \\ E-mail: junzhou_9@hotmail.com \\ ${ }^{2}$ Faculty of Economics and Business, UNIVERISITI MALAYSIA SARAWAK, MALAYSIA. E-mail: mclo@unimas.my \\ ${ }^{3}$ School of Management, UNIVERSITI SAINS MALAYSIA, MALAYSIA. E-mail: ramayah@usm.my \\ ${ }^{4}$ Faculty of Economics and Business, UNIVERISITI MALAYSIA SARAWAK, MALAYSIA. \\ E-mail: maazlan@unimas.my
}

\begin{abstract}
Ecotourism or sustainable tourism, which is often advocated especially in natural areas for relaxation. The richness of natural areas in Malaysia has led ecotourism to become one of the fast-growing industries within the nation. A full understanding of ecotourism practices in planning, development and resource management is therefore needed to ensure sustainability without causing environmental degradation. The goal of this study is to discover the impacts of created resources (e.g.: tourism infrastructure and range of activities) and supporting resources (e.g.: destination accessibility and quality of tourism services) towards competitiveness of tourism destinations from both the perspective of domestic and international tourists along with the moderation of social media marketing.
\end{abstract}

Keywords: Tourism Infrastructure; Range of Activities; Destination Accessibility; Quality of Tourism Services; Competitiveness; Social Media Marketing.

JEL Classification: C12, M31, Z32 